\title{
Yksityisen ja julkisen rajanvedon historia
}

\author{
Ville Yliaska (2014). Tehokkuuden toiveuni. Uuden julkisjohtamisen historia Suomessa \\ 1970-luvulta 1990-luvulle. Helsinki: Into Kustannus. 600 s. ISBN: 978-952-264-318-6
}

UUSI JULKISJOHTAMINEN (New Public Management, NPM) levisi Suomeen 1970-1990-luvuilla, ja sen vaikutukset ulottuvat tähän päivään. NPM:n seurauksena yksityisen ja julkisen sektorin jaottelu muuttui häilyvämmäksi, mutta se muutti myös suhtautumista hyvinvointivaltioon ja julkisen sektorin työntekijöihin.

Ville Yliaskan huolellinen ja kunnianhimoinen historiatieteellinen väitöskirjatutkimus Tehokkuuden toiveuni kertoo uuden julkisjohtamisen historian Suomessa.

Lukuisiin arkistolähteisiin ja aikalaiskirjoituksiin perustuva tutkimus ei aiemmista NPMtutkimuksista poiketen tyydy kuvaamaan kohdettaan vain hallinnollisena rationalisointina, vaan tarkastelee sitä osana yhteiskuntapolitiikkaa. Kuvatessaan tarinan keskeisten toimijoiden (kuten valtiovarainministeriö, puolueet, poliitikot, valtio, kunnat, virkamiehet ja hallintotieteilijät) uudistuksista käymiä neuvotteluja Yliaska politisoikin niihin liittyvän taloudellisen ideologian.

\section{YKSITYISKOHDAT}

\section{HÄMÄRTÄVÄT}

\section{KOKONAISKUVAA}

Tehokkuuden toiveuni muodostaa tarinan, jonka tehtävänä on ratkaista arvoitus: miten vuosikymmenien mittaista uudistusaaltoa pystyttiin pitämään yllä, vaikka todisteita uudistusten vaikutuksista ei ollut käytettävissä? Koska 600-sivuisen teoksen lukeminen vaatii ainakin kiireiseltä lukijalta hieman kärsivällisyyttä, kerron tarinan juonen pääpiirteissään, vaikka se ei teekään oikeutta tutkijan esiin nostamille lukuisille yksityiskohdille. Teos ei nimittäin sovellu kovinkaan hyvin sieltä täältä selailtavaksi, sillä se pyrkii antamaan kokonaiskuvan tapahtumista ja toimijoista.

Tarina alkaa 1970-luvun öljykriisistä ja keynesiläisen talousajattelun suosion kaatumisesta. NPM:n kannalta näiden tapahtumien tärkein vaikutus oli se, että usko hyvinvointivaltioon koki kolauksen. Talousongelmat esitettiin hyvinvointivaltion kriisinä ja julkisesta sektorista tuli taloudellinen taakka. Tässä ilmapiirissä NPM:n taustalla vaikuttanut uusoikeistolainen talousajattelu tarjosi selkeän poliittisen ohjelman, jonka luvattiin ratkaisevan kriisin. Keskeiset lääkkeet olivat julkisen sektorin yksityistäminen ja markkinaistaminen.

Yliaska taustoittaa ja kuvaa tärkeimmät NPM-uudistukset Suomessa, joiksi hän lukee valtionyhtiöiden liikelaitostamisen ja sittemmin yhtiöittämisen, yksityiseltä sektorilta omaksutut johtamismallit sekä erilaiset kvasimarkkinamallit, kuten monissa kunnissa käyttöönotetut tilaaja- tuottajamallit. Näiden reformien kuvaus on yksityiskohtaista, jopa pikkutarkkaa, ja tuo hyvin esiin uudistuksiin osallistuneet toimijat ja neuvottelut. Välillä lukijan on kuitenkin vaikea seurata tarinaa, sillä aineistot saavat yhtä suuren painoarvon. Sen vuoksi on vaikea arvioida, mitkä kehityskulut ovat olleet erityisen tärkeitä. Toisinaan tarina eksyy sivupoluille, ikään kuin kirjoittaja ei malttaisi jättää yhtään kiveä kääntämättä. Siksi hyppäänkin suoraan tarinan loppuun, jossa juoni vasta kunnolla valkenee lukijalle.

\section{TEHOKKUUDEN KASVUA VAIKEA MITATA}

Yliaska arvioi NPM-uudistusten onnistumista tutkimusten valossa. Uuden julkisjohtamisen toivottiin ensinnäkin tuovan valtiolle säästöjä leikkausten ja menojen kasvun pysäyttämisen muodossa, missä NPM-keinot toimivatkin. Kuntien valtionosuuksia leikattiin ja rahoitusvastuuta siirrettiin kunnille ja edelleen kansalaisille korotettujen kunnallisverojen ja palvelumaksujen muodossa. Toinen NPM:n lupaus oli propagandistisesti tärkeämpi: markkinaistaminen lisäisi tehokkuutta, tuottavuutta ja laatua sekä vähentäisi byrokratiaa.

Vastaus kysymykseen, tapahtuiko näin, on juonen kannalta äärimmäisen kiinnostava. Vastaus 
nimittäin on: emme tiedä. Suurin osa Yliaskan tarkastelemista tutkimuksista ei sisältänyt tietoa tehokkuuden kasvusta, vaan ainoastaan kuvaili tapahtuneita muutoksia. Syynä oli usein se, ettei ollut olemassa riittävän hyviä mittareita, ja harva tiesi lähtötason. Ne harvat tutkimukset, joissa tehokkuutta ja tuottavuutta oli mitattu, antoivat ristiriitaisen kuvan.

Paradoksaalista kyllä, vakiintunein NPM:n vaikutuksia koskeva tutkimustulos on työelämän heikentyminen julkisella sektorilla. "Näennäismarkkinoita tavoittelevat reformit ovat tuotteistaessaan osittaneet, byrokratisoineet ja intensivoineet julkisen sektorin työt uupumustilastojen kärkisijoille", Yliaska kirjoittaa (s. 509).

\section{TALOUS MUUTTUU - NIIN MYÖS IHMISKUVA}

Tämä pohjustaa tarinan kliimaksia: Yliaskan mukaan NPM oli osa prosessia, jossa julkisen sektorin perusrakenteita muokattiin hyvinvointivaltiosta valmentajavaltioksi. Tavoitteena ei siis ollut vain tehostaa julkisen sektorin toimintaa ja pienentää sen kokoa, vaan keskittää valtaa julkisista resursseista kunnilta valtiolle ja valtionhallinnon sisällä keskusvirastoilta ministeriöille ja sektoriministeriöiltä valtiovarainministeriön budjettiosastolle.

Keskitettyä resurssivaltaa käytettiin julkisten varojen siirtämiseen hyvinvointipalveluista valmentajavaltion tarpeisiin, ennen kaikkea elektroniikkateollisuuden tutkimus- ja kehitystyöhön sekä riskirahoitukseen.
Valtiointerventionistinen teollisuuspolitiikka selittää tutkijan mukaan myös sen, minkä vuoksi uudistuksia voitiin tehdä niin pitkään ilman todisteita niiden vaikutuksista. Vaikutuksilla ei ollut käytännössä merkitystä, sillä päätavoitteet olivat resurssivallan keskittämisessä ja julkisen sektorin pienentämisessä. Siksi NPM:n propagandistisesti tärkein osa eli toiminnan tehostaminen jäi sivurooliin. Ilman tätä lupausta resurssien leikkauksia olisi kuitenkin ollut vaikeampi perustella.

Tarinan lukuisista yksityiskohdista kenties kiinnostavin on talousajattelun muuttumisen rinnalla kulkenut ihmiskuvan muutos. NPM:n juuret ovat julkisen valinnan teoriassa, jonka mukaan ihmiset toimivat omia intressejään maksimoiden. Omaa henkilökohtaista etua ajaessaan julkisella sektorilla toimivat yksilöt kasvattivat julkista sektoria. Markkinamekanismien avulla virkamiesten ja poliitikoiden valta voitiin kuitenkin minimoida ja valjastaa oman edun tavoittelu tehokkuuden parantamiseen.

Uusi ihmiskuva oli kaksijakoinen: hallinnon kehittäjien ja sitä kannattavien poliitikkojen nähtiin toteuttavan uudistuksia kansakunnan parasta ajatellen, kun taas kaikkien heitä hierarkiassa alempana toimivien julkisen sektorin työntekijöiden ajateltiin toimivan lyhytnäköisen itseintressin ohjaamina.

\section{TIIVISTÄMÄLLÄ UUSIA}

\section{LUKIJOITA?}

Kiehtoviin yksityiskohtiin kuuluvat myös kirjoittajan tarjoamat välähdykset talousajattelun ja siihen liittyvien metaforien sukupuolittuneisuudesta. Leikkausten kohteenahan oli feminiininen hyvinvointivaltio stereotyyppisine sairaanhoitajineen ja "sosiaalitanttoineen", joiden ajateltiin "liian äidillisesti hemmottelevan hoidettaviaan ja kuluttavan tuottamattomiin kohteisiin vientiteollisuuden isien kotiin tuomaa rahaa" (s. 367).

Kiinnostava jatkotutkimuksen aihe olisikin, miten NPM on vaikuttanut naisten ja miesten työelämän laadun eriytymiseen.

Opinnäytteen jalostaminen hieman tiiviimmän kirjan muotoon olisi saattanut laajentaa sen lukijakuntaa, sillä nyt siihen tarttuminen saattaa jäädä väliin poliitikoilta ja hallinnon kehittäjiltä. Kokonaisuudessaan teos auttaa ymmärtämään viime vuosikymmenien yhteiskunnallisia muutoksia laajasti ja tarjoaa niihin uusia näkökulmia. Siihen tutustumista voikin suositella kaikille hyvinvointivaltion tilasta ja tulevaisuudesta kiinnostuneille.

Hanna Ylöstalo

YTT, sukupuolentutkimuksen yliopistonlehtori

Turun yliopisto 